\title{
Sanitary problems related to the presence of Ostreopsis spp. in the Mediterranean Sea: a multidisciplinary scientific approach
}

\author{
Giorgia Del Favero $^{(\mathrm{a})}$, Silvio Sosa ${ }^{(\mathrm{a})}$, Marco Pelin ${ }^{(\mathrm{a})}$, Elisabetta D'Orlando ${ }^{(\mathrm{a})}$, \\ Chiara Florio $^{(\mathrm{a})}$, Paola Lorenzon ${ }^{(\mathrm{a})}$, Mark Poli ${ }^{(\mathrm{b})}$ and Aurelia Tubaro ${ }^{(\mathrm{a})}$ \\ ${ }^{(a)}$ Dipartimento di Scienze della Vita, Università degli Studi di Trieste, Trieste, Italy \\ (b) United States Army Medical Research Institute of Infectious Diseases, Fort Detrick, Maryland, USA
}

\begin{abstract}
The increased presence of potentially toxic microalgae in the Mediterranean area is a matter of great concern. Since the end of the last century, microalgae of the genus Ostreopsis have been detected more and more frequently in the Italian coastal waters. The presence of Ostreopsis spp. has been accompanied by the presence of previously undetected marine biotoxins (palytoxins) into the ecosystem with the increased possibility of human exposure. In response to the urgent need for toxicity characterization of palytoxin and its congeners, an integrated study encompassing both in vitro and in vivo methods was performed.
\end{abstract}

Key words: Ostreopsis, palytoxin (PLTX), acute toxicity, myotoxicity, cutaneous toxicity.

\begin{abstract}
Riassunto (Problemi sanitari relativi alla presenza di Ostreopsis spp. nel Mar Mediterraneo: un approccio scientifico multidisciplinare). La sempre maggiore presenza di microalghe potenzialmente tossiche nell'area mediterranea è motivo di grande preoccupazione. Dalla fine del secolo scorso, microalghe appartenenti al genere Ostreopsis sono state isolate con sempre maggiore frequenza nelle acque costiere italiane. La presenza di specie di Ostreopsis è stata accompagnata dalla comparsa di biotossine marine (palitossine), mai isolate prima nell'ecosistema, con conseguente aumento della probabilità di esposizione umana. In risposta al bisogno urgente di caratterizzazione della tossicità della palitossina e dei composti strutturalmente correlati, è stato scelto un approccio di studio integrato tra metodiche in vitro e in vivo.
\end{abstract}

Parole chiave: Ostreopsis, palitossina (PLTX), tossicità acuta, miotossicità, tossicità cutanea.

\section{INTRODUCTION}

Microalgae of Ostreopsis spp. are unicellular epiphytic benthic dinoflagellates $[1,2]$ : originally, they were thought to colonize only tropical and sub-tropical areas, but they are now being detected more and more frequently in temperate seas [3, 4], suggesting their geographic spread in the benthic environment. Concern about the distribution of Ostreopsis is motivated by its high potential for toxicity [4]. The entrance of potentially toxic dinoflagellates into the ecosystem can have impacts at several levels. In general, sanitary and economic consequences, often tightly connected, are of the greatest concern. In the Mediterranean region, appearance and proliferation of Ostreopsis spp. were first recorded in the late 1970s and 1980s [5, 6]. In Italy, the presence of Ostreopsis ovata was recorded for the first time in 1994, along the coasts of the Lazio region [7]. Since then, the presence of Ostreopsis spp., most often $O$. cf. ovata, has been recorded several times along the Italian coastline [8-21], including the northern areas, such as the Gulf of Genoa [19, 22, 23] and the Gulf of Trieste (Figure 1) [19, 24, 25].
Globally, attention shifted toward Ostreopsis in 1995, when Dr. Takeshi Yasumoto's group isolated and characterized PLTX-like compounds from $O$. siamensis [26-27]. Until this time, the origin of palytoxins was thought to be soft corals of the genus Palythoa [28]. Since then, there has been increasing consensus in the scientific community regarding microalgae as at least one producer of the toxins, even though the biosynthetic pathways are still unclear and represent a field of open and ongoing research. In addition to $O$. siamensis, putative PLTX and analogues have been isolated from $\mathrm{O}$. mascarenensis [29] and $O$. ovata [30-35]. Extensive studies on Ostreopsis samples has led to the identification of several PLTX congeners (Figure 2), including ostreocin-D [26, 27], mascarenotoxins [29-34] and several ovatoxins, denoted ovatoxin-a, -b, -c, -d, -e [30-34] and ovatoxin-f [35].

Palytoxin is considered among the most toxic compounds of natural origin ever isolated. It impairs the function of the $\mathrm{Na}^{+} / \mathrm{K}^{+}$-ATPase [36-39], whose physiological activity is of crucial importance for eukaryotic cells. Since 2006, our research group at 


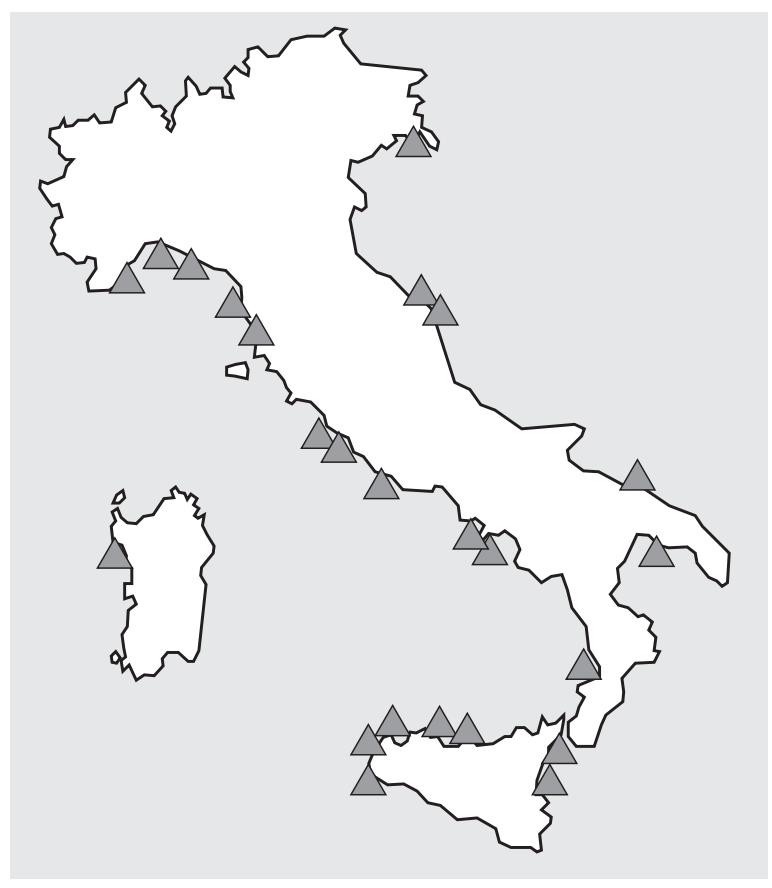

Fig. 1 Schematic representation of the sites of Ostreopsis blooms along the Italian coasts. (Data sources: [7-21]; http:// arpa.sicilia.it and A. Penna, personal communication).

the University of Trieste has followed the PLTXphenomenon and added the study of PLTXs to the ongoing research on other algal toxins. This mini-review is mainly focused on the results obtained by our research group on this topic. Considering the potential different route of exposure to these toxins and the possible scenarios of intoxication, starting from the available data, an integrated in vivo and in vitro approach, including toxicological, physiological, cellular biology and biochemical studies, was adopted. This mini-review mainly summarizes the results of these studies, aimed to characterize PLTXs toxicity, and to identify the target organs and the mechanism at the basis of the toxic effects, useful also to provide a suitable therapeutic approach.

\section{Potential exposure to Ostreopsis spp. and the related toxins into marine aerosols and seawater: possible health effects}

In the Mediterranean area, the increasing proliferation of Ostreopsis spp. along the coastlines was accompanied by the occurrence of human intoxication $[10,40-43]$. In particular, human exposure to marine aerosol and/or seawater concomitantly to Ostreopsis proliferations was associated with an illness in which symptoms involved mainly the upper respiratory tract [40]. The cause-effect correlation between the cases of malaise and the involvement of algal toxins has not been completely clarified: in fact palytoxins were never detected in marine aerosol so far, even though these toxins were quantified in field algal samples [31]. Furthermore, although Ostreopsis cells concentrations were determined in seawater, these data are not predictive for human risk since dinoflagellates do not always produce the same amount of toxins, if any [25]. Ostreopsis cell debris can be also present in the marine aerosol and their contribution to the ef-

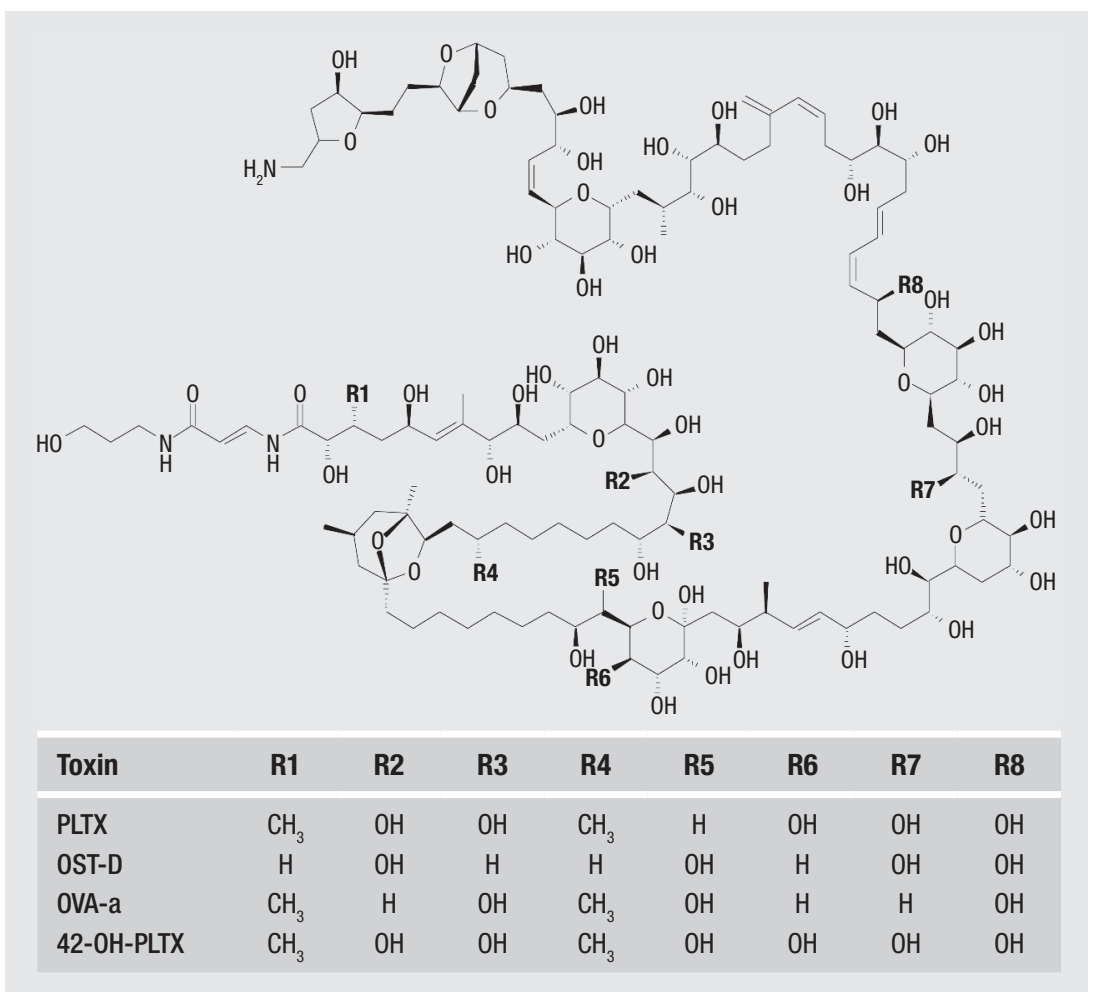

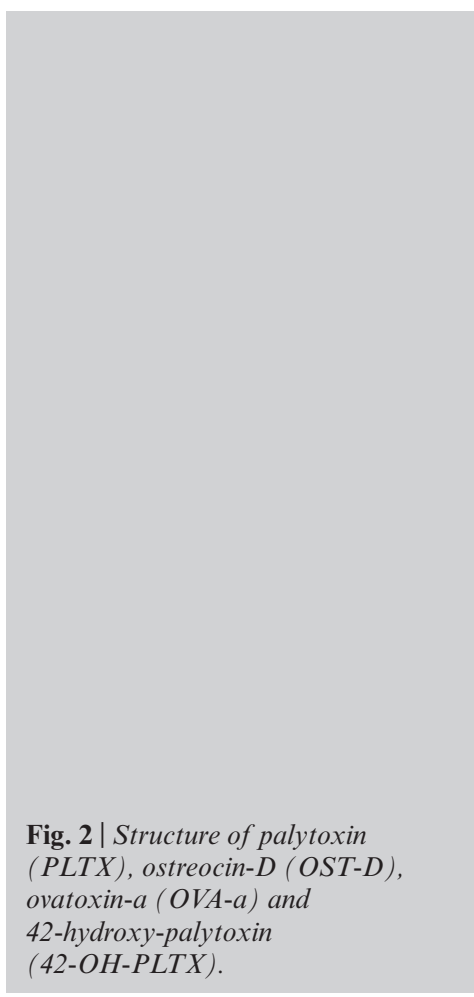


fects on human health cannot be excluded. Anyway, the recurrence of sanitary problems associated with Ostreopsis blooms suggests a relationship between these phenomena [43].

Along the Italian coastlines, the first documented health problems associated with Ostreopsis blooms were described as general malaise in people exposed both to seawater and/or marine aerosol in Tuscany [9] and Apulia [8]. Later, symptoms such as rhinorrhea, cough, dyspnea and fever, associated with blooms along the Bari coast, were described in more detail by Gallitelli, et al. [10]. Similar symptoms were observed along the Spanish and French Mediterranean coasts, accompanied by ocular irritation, headache and, in some cases, by fever [41, 42]. Other anecdotal descriptions of respiratory problems following marine aerosol exposure during Ostreopsis blooms have also been reported along the Mediterranean coast [25, 43, 44]. The most serious sanitary problems occurred on the Liguria coast in summer of $2005[22,40]$ and repeated, with a lower intensity, in 2006 [40]. In July 2005, more than 200 people enjoying the Genoa beach and promenade suffered an unusual influenza-like syndrome, characterized by a wide spectrum of symptoms such as fever, sore throat, cough, dyspnea, headache, nausea, rhinorrhea, lacrimation, vomiting and dermatitis. Approximately $20 \%$ of patients required hospitalization (1-3 days), and some of them needed the intensive care unit of the local hospitals [40]. This occurrence represents the most severe incident described to date in terms of both the number of people affected and for the severity of the symptoms.

In addition to the problems at the respiratory level, skin irritation was frequently observed after aerosol exposure and/or seawater contact during Ostreopsis blooms. Indeed, in summer 2005, concomitant with marine aerosol exposure during Ostreopsis ovata blooms in Genoa (Northern Italy), the incidence of dermatitis was 5\% [40]. Erythematous dermatitis was also observed by Gallitelli (personal communication) in patients exposed to marine aerosols during Ostreopsis blooms, along Apulia coasts (Southern Italy) [43].

Although the actual cause of this dermatitis has not yet been unequivocally determined, dermal toxicity has been associated to PLTX-like molecules contaminating other marine organisms [43, 45]. For instance, skin toxicity has been reported after handling zoanthids (Palythoa) used as aquarium decorative corals: persistent signs of dermotoxicity and perioral paresthesia were attributed to PLTX in a patient with intact skin [46]. Another case of skin toxicity due to handling PLTX-containing zoanthid corals (Parazoanthus spp.) involved a patient who cut his fingers while cleaning his aquarium. Dermal distress with swelling, paresthesia and numbness around the site of injury, as well as systemic symptoms, were recorded [47]. Despite the reports on human dermal toxicity attributed to PLTXs, very little data regarding skin toxicity are presently available in the scientific lit- erature. Our group contributed to the elucidation of the cutaneous effects of the parent compound PLTX: an in vitro toxicity study was carried out using the human $\mathrm{HaCaT}$ keratinocytes [48], a predictive model for the evaluation of skin toxicity and an ideal model for first-round screening of dermotoxic agents [49]. The cytotoxicity of PLTX on HaCaT cells was investigated after a short time exposure $(4 \mathrm{~h})$ and different cellular endpoints were evaluated. PLTX reduced mitochondrial activity (MTT assay), cell viability (sulforhodamine B assay) and plasma membrane integrity (LDH leakage), albeit with different potencies $\left(\mathrm{EC}_{50}=6.1 \pm 1.3 \times 10^{-11} \mathrm{M}, 4.7 \pm 0.9 \times 10^{-10} \mathrm{M}\right.$ and 1.8 $\pm 0.1 \times 10^{-8} \mathrm{M}$, respectively). These data suggest that the sequence of intracellular events following the interaction of PLTX with its molecular target includes mitochondrial damage, causing a reduction in cell viability and plasma membrane rupture, with resulting leakage of LDH. Moreover, mitochondrial dysfunction was tentatively associated with oxidative stress, since PLTX induced superoxide anion accumulation after only $1 \mathrm{~h}$ exposure [48]. All these effects were inhibited by the presence of ouabain, a cardiac glycoside that inhibits PLTX binding to its molecular target $\left(\mathrm{Na}^{+} / \mathrm{K}^{+}\right.$-ATPase). These data demonstrated the dependency of PLTX cytotoxicity on the interaction with the pump, which is transformed by PLTX into a non-selective cationic pore [37-39, 50]. The main consequence of this interaction seems to be a sustained intracellular overload of $\mathrm{Na}^{+}$, followed by an overload of $\mathrm{Ca}^{2+}$ [51-54]. Consequently, the mechanism of PLTX cytotoxicity was investigated, with particular attention to the ionic imbalance induced by the toxin. On $\mathrm{HaCaT}$ cells, removal of $\mathrm{Na}^{+}$from the cell medium almost completely abolished: $i$ ) PLTX-induced oxidative stress, $i i)$ impairment of mitochondrial activity and iii) appearance of morphological changes, demonstrating that intracellular $\mathrm{Na}^{+}$accumulation is the first and crucial step in mediating PLTX-induced early cell damage. By contrast, $\mathrm{Ca}^{2+}$ withdrawal did not affect PLTX-induced oxidative stress or cell morphology, confirming the $\mathrm{Na}^{+}$-dependency of these effects on HaCaT keratinocytes [48].

\section{Potential exposure to Ostreopsis spp. and related toxins via seafood: possible health effects}

The presence of toxic Ostreopsis species into the ecosystem is related to the entrance of their toxins into the food web. The accumulation of biotoxins in the food web is a common, naturally occurring phenomenon [55], but it may lead to significant concentrations of toxic compounds in edible organisms and represent a potential threat to human health. Palytoxins are no exception and have been detected in several species of crustaceans, fish, mollusks and echinoderms, even if the consequences of their accumulation seem to differ from area to area [56-65]. In tropical and subtropical areas, accumulation of PLTXs in fish and crustacean lead to some cases of intoxication, even with lethal outcomes [43, 57-60]. In Madagascar, for instance, a lethal human intoxication 
has been reported resulting from ingestion of PLTXcontaminated sardine sharing habitat with Ostreopsis [59]. In the Mediterranean area, contamination involved mainly mollusks and echinoderms, such as shellfish and sea urchins $[19,61-66]$ but, to date, no case of human intoxication has been described. In Italy, palytoxins were detected mainly in the frame of monitoring programs $[19,64]$. The presence of ovatoxin-a $(303-625 \mu \mathrm{g} / \mathrm{kg})$ has been reported mainly in wild mussels collected along the rocky Italian coasts [64]. Similarly, in France, contamination reached 450 $\mu \mathrm{g}$ PLTX equivalents $/ \mathrm{kg}$ of total flesh of sea urchins and $230 \mu \mathrm{g}$ PLTX equivalents $/ \mathrm{kg}$ of total flesh of mussels [65]. PLTXs and related toxins are not routinely tested, because no regulation at Italian or European level currently include them in the monitoring programs. Moreover, in Mediterranean Sea, the most abundant PLTXs detected in seafood are ovatoxins, and in particular ovatoxin-a, not yet available in sufficient amounts for oral toxicological studies, that are necessary for regulatory purposes.

Anyway, EFSA suggested $30 \mu \mathrm{g}$ PLTXs (sum of PLTX and ostreocin-D)/kg shellfish meat as maximum level in shellfish [63]. However, this value is based on the limited available toxicological studies carried out in mice with the pure toxins after oral, sublingual and intratracheal exposure, the last one being not representative in humans for this evaluation. Other toxicological studies on PLTX were initially performed immediately after its discovery: no effects were observed in rats after oral administration of $40 \mu \mathrm{g} / \mathrm{kg}$ of a compound, which molecular weight was $3300 \mathrm{Da}$ [67], nearly $500 \mathrm{Da}$ higher than that currently reported for PLTX. More than thirty years later, an $\mathrm{LD}_{50}=510 \mu \mathrm{g} / \mathrm{kg}$ was estimated for PLTX in mice, evaluating only lethality as endpoint of toxicity [68]. Subsequently, Ito and Yasumoto [69] reported tissue damages induced by the oral administration of PLTX or ostreocin-D (200 or $500 \mu \mathrm{g} / \mathrm{kg}$ ). To implement the toxicological characterization, the acute oral toxicity of PLTXs in mice was evaluated increasing the dosages and expanding the panel of endpoints (i.e. histological and hematoclinical analyses). The toxicity was initially evaluated, within $24 \mathrm{~h}$ after the administration, on the parent compound PLTX and it was found to be strictly dose-related [70]. Later, the study was repeated on 42-hydroxy-PLTX [71], chemically characterized in 2009 [72] (Figure 2). Similar in structure, PLTX and 42-hydroxy-PLTX also resulted in similar toxicity and symptoms. During the observation period, some of the mice presented scratching, jumping, paralysis of the hind limbs, respiratory distress, occasionally accompanied by cyanosis and died within $24 \mathrm{~h}$ from the administration of the toxins. Histological analysis revealed decreased glycogen content in hepatocytes. Mice that survived the treatment exhibited several degrees of inflammation of the mucosa in the forestomach [70,71].

In animals treated from the dose of $600 \mu \mathrm{g} / \mathrm{kg}$, hematochemical analysis revealed alteration in plasma levels of creatine phosphokinase (CPK), lactate dehydrogenase (LDH) and aspartate transaminase (AST), suggesting involvement of the muscular tissue in the toxicity of PLTX and 42-hydroxy-PLTX $[70,71]$. In animals treated with PLTX, dose-dependent ultrastructural alterations of skeletal and cardiac muscle were also observed. The identification of skeletal muscle as one of the targets for PLTX was in agreement with the epidemiological data [43], which revealed that, in the majority of human cases, muscular problems and myalgia were reported as distinctive features [57, 58,60]. For this reason, cultures of mouse skeletal muscle cells were chosen as a suitable model for the deeper investigation of the mechanism of action of both PLTX [73] and 42-hydroxy-PLTX (Del Favero et al., in preparation). As mentioned above, PLTX is known to impair the activity of the $\mathrm{Na}^{+} / \mathrm{K}^{+}$pump, with dramatic consequences on cellular ionic homeostasis [36-39, 50]. As well as high toxicity, quite common to all the cells models tested so far [74], PLTXs triggered an uncontrolled intracellular calcium $\left(\left[\mathrm{Ca}^{2+}\right]_{\mathrm{i}}\right)$ increase $[72,73]$ and morphological alterations [73]. These events seemed to be strictly related to the development of the toxic insult [73]. The $\left[\mathrm{Ca}^{2+}\right]_{\mathrm{i}}$ increase consisted of a transitory $\mathrm{Ca}^{2+}$ response (transient phase) followed by a slower and more sustained $\left[\mathrm{Ca}^{2+}\right]_{\mathrm{i}}$ increase (long-lasting phase). The transient phase was sustained by the $i$ ) activation of voltagedependent $\mathrm{Ca}^{2+}$ channels, ii) $\mathrm{Na}^{+} / \mathrm{Ca}^{2+}$ exchanger (reverse mode) and iii) $\mathrm{Ca}^{2+}$ release from intracellular stores with no influence on the PLTX-mediated toxicity. The long-lasting phase seemed to be sustained by the activation of stretch-activated channels and represents a crucial step in the development of the myotoxic insult [73]. PLTXs did not only severely impair cellular viability, but also altered the functional properties of skeletal muscle cells, such as the ability to respond to physiological stimuli [73] (Del Favero et al., in preparation). On the whole, the skeletal muscle cell cultures allowed the characterization of the ionic disequilibrium triggered by PLTXs, opening new insight into the mechanism of action of PLTX at the single cell level.

The alterations at the muscular level observed in mice after acute PLTX oral exposure, together with the epidemiological observations in humans (lethality, muscle cramps, myalgia, and cardiac alterations) suggest PLTX absorption in the gastrointestinal tract after oral exposure. Thus, information on the gastrointestinal absorption of PLTX seemed to be pivotal for a rational risk assessment. Since no toxicokinetic data on PLTX were available, an in vitro study was carried out for the evaluation of PLTX absorption through the intestinal barrier: to this aim the human Caco-2 cell line was used. However, Caco-2 cells are one of the most sensitive cell models for PLTX, presenting reduced viability at the sub pico-molar range $\left(\mathrm{EC}_{50}=8.9 \pm 3.7 \times 10^{-12} \mathrm{M}\right.$ after $4 \mathrm{~h}$ exposure, MTT assay). Unfortunately, the high sensitivity of this model precluded the possibility of evaluating PLTX absorption [75]. 


\section{DISCUSSION AND CONCLUSIONS}

The relative rapidity that characterizes the entrance of new species of potentially harmful microalgae in the Mediterranean ecosystems represents an immense challenge from the scientific and regulatory point of view. The data necessary for the evaluation of real toxicological hazard beneath naturally occurring phenomena, such as algal blooms, require time and resources. Thus, even though Ostreopsis appeared in Mediterranean waters over 30 years ago [5], the toxicological consequences of exposure to its suite of toxins is still an open research field.

A multidisciplinary scientific approach for the toxicological characterization of PLTXs based on literature and epidemiological data was followed. Initially, wider in vivo acute toxicity studies allowed to individuate the skeletal muscle as one of the main targets of PLTXs toxicity, in agreement with human symptoms. Although no structural alterations were observed in mice, the sharp increase in $\mathrm{CPK}, \mathrm{K}^{+}$and LDH plasma levels suggested the skeletal muscle involvement, subsequently confirmed by ultra-structural changes. Further in vitro studies on skeletal muscle cells contributed to the elucidation of PLTX effects at functional level and to the characterization of its mechanism of action, opening new perspectives.

The lack of toxicokinetic data on PLTX and the difficulty of predicting absorption and distribution in the body is still a challenge for the comprehension of the hazard associated with PLTXs in the food web. Moreover, the accumulation of the toxins in several edible marine species [19, 56-65] opens the possibility of repeated human exposure through contaminated seafood collected in the same area.

Considering exposure routes different from the oral one, the cutaneous toxicity was characterized using an in vitro approach. The high toxicity of PLTX on skin keratinocytes [48] raises valid concerns about the potential human exposure to PLTX-related toxins in

\section{References}

1. Schmidt J. Peridiniales. Bot Tidsskr 1901;24:212-21.

2. Fukuyo Y. Taxonomical study of benthic dinoflagellates, collected in coral reef. Bull Jap Soc Sci Fish 1981;47:967-78. http://dx.doi.org/10.2331/suisan.47.967

3. Shears NT and Ross PM. Blooms of benthic dinoflagellates of the genus Ostreopsis; an increasing and ecologically important phenomenon on temperate reefs in New Zealand and worldwide. Harmful Algae 2009;8:916-25. http://dx.doi.org/10.1016/j.hal.2009.05.003

4. Rhodes L. World-wide occurrence of the toxic dinoflagellate genus Ostreopsis Schmidt. Toxicon 2011;57:400-7. http://dx.doi.org/10.1016/j.toxicon.2010.05.010

5. Taylor FJR. A description of the benthic dinoflagellate associated with maitotoxin and ciguatoxin, including observations on Hawaiian material. In: Taylor DL, Seliger HH (Eds.). Toxic dinoflagellate blooms. North-Holland, New York: Elsevier; 1979. p. 71-6.

6. Abboud-Abi Saab M. Les dinoflagelleés des eaux côtières libanaises-espèces rares ou nouvelles du phytoplankton marin. Lebanese Science Bulletin 1989;5:5-16. seawater and needs to be further investigated. These data will help the prevention of toxicity for people exposed to seawater during Ostreopsis blooms, either professionally or recreationally. Toxicological evaluation of PLTX-like compounds after inhalational exposure remains one of the most crucial issues, and should be addressed as soon as possible by the scientific community.

In conclusion, sanitary problems related to Ostreopsis spp. could be due to the entrance of previously absent toxins into the food web and to human exposure to marine aerosols and/or seawater during large algal blooms. A multidisciplinary approach to the problem should be further adopted for their complete exploitation and evaluation. The number of known toxins is constantly increasing, requiring additional efforts for toxicity characterization. Studies are urgently needed to evaluate the effects of these toxins after repeated oral exposure. Another crucial point is the characterization of the oral toxicity of the new ovatoxin analogues as well as of their inhalational toxicity.

\section{Acknowledgments}

This work was supported by the Italian Ministry of Education University and Research (PRIN2009JS5YX9_002) and Regione Friuli-Venezia Giulia, Direzione Risorse Rurali, Agroalimentari e Forestali (Progetto "Kit e biosensori di elevata sensibilità per la determinazione delle tossine di alghe nelle acque e nei prodotti ittici del Friuli-Venezia Giulia - Senstox"). The authors are grateful to G. Honsell (University of Udine), to G. Decorti (University of Trieste), to R. Cefalo (GeoSNav, University of Trieste) and to A. Penna (University of Urbino) for their stimulating support.

\section{Conflict of interest statement}

There are no potential conflicts of interest or any financial or personal relationships with other people or organizations that could inappropriately bias conduct and findings of this study.

Submitted on invitation.

Accepted on 24 September 2012.

7. Tognetto L, Bellato S, Moro I, Andreoli C. Occurrence of Ostreopsis ovata (Dinophyceae) in the Tyrrhenian Sea during summer 1994. Bot Mar 1995;38:291-5. http://dx.doi.org/10.1515/botm.1995.38.1-6.291

8. Di Turi L, Lo Caputo S, Marzano MC, Pastorelli AM, Pompei M, Rositani L, et al. Ostropsidiaceae (Dynophyceae) presence along the coastal area of Bari. Biol Mar Mediterr 2003;10:675-8.

9. Sansoni G, Borghini B, Camici G, Casotti M, Righini P, Rustighi C. Fioriture algali di Ostreopsis ovata (Gonyaulacales: Dinophyceae): un problema emergente. Biologia Ambientale 2003; 17:17-23.

10. Gallitelli M, Ungaro N, Addante LM, Gentiloni Silver M, Sabbà C. Respiratory illness as a reaction to tropical algal bloomsoccurringinatemperateclimate. JAMA2005;293:2599600 .

http://dx.doi.org/10.1001/jama.293.21.2599-c

11. Penna A, Vila M, Fraga S, Giacobbe MG, Andreoni F, Riobò P, et al. Characterization of Ostreopsis and Coolia (Dinophyceae) isolates in the Western Mediterranean Sea based on morphology, toxicity and internal transcribed spacer 5.8S rDNA sequences. $J$ Phycol 2005;41:212-25. http://dx.doi.org/10.1111/j.1529-8817.2005.04011.x 
12. Penna A, Fraga S, Battocchi C, Casabianca S, Giacobbe MG, Riobó P, et al. Phylogeographical study of the toxic benthic dinoflagellate genus Ostreopsis Schmidt. J Biogeogr 2010;37:830-41. http://dx.doi.org/10.1111/j.1365-2699.2009.02265.x

13. Zingone A, Siano R, D'Alelio D, Sarno D. Potentially toxic and harmful microalgae from coastal waters of the Campania region, Tyrrhenian Sea, Mediterranean Sea. Harmful Algae 2006;5:321-37. http://dx.doi.org/10.1016/j.hal.2005.09.002

14. Barone R. Behavioral trait of Ostreopsis ovata (Dinophyceae) in the Mediterranean rock pools: the spider strategy. Harmful Algal News 2007;33:1-3.

15. Totti C, Cucchiari E, Romagnoli T, Penna A. Bloom of Ostreopsis ovata on the Conero riviera (NW Adriatic Sea). Harmful Algae News 2007;33:12-3

16. TottiC,AccoroniS, Cerino F, CucchiariE, RomagnoliT. Ostreopsis ovata bloom along the Conero Riviera (Northern Adriatic Sea): Relationships with environmental conditions and substrata. Harmful Algae 2010;9:233-9. http://dx.doi.org/10.1016/j.hal.2009.10.006

17. Guerrini F, Pezzolesi L, Feller A, Riccardi M, Ciminiello P, Dell'Aversano C, et al. Comparative growth and toxin profile of cultured Ostreopsis ovata from the Tyrrhenian and Adriatic Seas. Toxicon 2010;55:211-20 http://dx.doi.org/10.1016/j.toxicon.2009.07.019

18. Accoroni S, Romagnoli T, Colombo F, Pennesi C, Di Camillo CG, Marini M, et al. Ostreopsis cf. ovata bloom in the northern Adriatic Sea during summer 2009: ecology, molecular characterization and toxin profile. Mar Pollut Bull 2011;62:2512-9. http://dx.doi.org/10.1016/j.marpolbul.2011.08.003

19. Istituto Superiore per la Protezione e la Ricerca Ambientale. Fioriture algali di Ostreopsis ovata lungo le coste italiane. ISPRA (ISPRA Atti, 2011).

20. Pagliara P, Caroppo C. Toxicity assessment of Amphidinium carterae, Coolia cfr. monotis and Ostreopsis cfr. ovata (Dinophyta) isolated from the northern Ionian Sea (Mediterranean Sea). Toxicon 2012;60:1203-14 http://dx.doi.org/10.1016/j.toxicon.2012.08.005

21. Istituto Superiore per la Protezione e la Ricerca Ambientale. Monitoraggio di Ostreopsis ovata ed altre microalghe potenzialmente tossiche lungo le coste italiane nel triennio 20072009. ISPRA (ISPRA Rapporti, n. 127/2010).

22. Brescianini C, Grillo C, Melchiorre N, Bertolotto R, Ferrari A, Vivaldi B, et al. Ostreopsis ovata algal blooms affecting human health in Genova, Italy, 2005 and 2006. EuroSurveill 2006;11(36):3040

23. Mangialajo L, Bertolotto R, Cattaneo-Vietti R, Chiantore M, Grillo C, Lemee R, et al. The toxic benthic dinoflagellate Ostreopsis ovata: quantification of proliferation along the coastline of Genoa, Italy. Mar Poll Bull 2008;56:1209-14.

http://dx.doi.org/10.1016/j.marpolbul.2008.02.028

24. Monti M, Minocci M, Beran A, Iveša L. First record of Ostreopsis cfr. ovata on macroalgae in the Northern Adriatic Sea. Mar Poll Bull 2007;54:598-601. http://dx.doi.org/10.1016/j.marpolbul.2007.01.013

25. Honsell G, De Bortoli M, Boscolo S, Dell'Aversano C, Battocchi C, Fontanive G, et al. Harmful dinoflagellate Ostreopsis cf. ovata Fukuyo: detection of ovatoxins in field samples and cell immunolocalization using antipalytoxin antibodies. Environ Sci Technol 2011;45:7051-9. http://dx.doi.org/10.1021/es201373e

26. Usami M, Satake M, Ishida S, Inoue A, Kan Y, Yasumoto T. Palytoxin analogs from the dinoflagellate Ostreopsis sia- mensis. J Am Chem Soc 1995;117:5389-90.

http://dx.doi.org/10.1021/ja00124a034

27. Ukena T, Satake M, Usami T, Oshima Y, Fujita T, Kan Y, et al. Structure elucidation of Ostreocin-D, a palytoxin analog isolated from the dinoflagellate Ostreopsis siamensis. Biosci Biotechnol Biochem 2001;65:2585-8. http://dx.doi.org/10.1271/bbb.65.2585

28. Moore RE, Scheuer PJ. Palytoxin: a new marine toxin from a coelenterate. Science 1971;172:495-8. http://dx.doi.org/10.1126/science.172.3982.495

29. LenoirS, Ten-HageL, TurquetJ, QuodPJ, BernardC, Hennion MC. First evidence of palytoxin analogues from an Ostreopsis mascarenensis (Dinophyaceae) benthic bloom in southwestern Indian Ocean. $J$ Phycol 2004;40:1042-51. http://dx.doi.org/10.1111/j.1529-8817.2004.04016.x

30. Ciminiello P, Dell'Aversano C, Fattorusso E, Forino M, Magno GS, Tartaglione L, et al. The Genoa 2005 outbreak. Determination of putative palytoxin in Mediterranean Ostreopsis ovata by a new liquid chromatography tandem mass spectrometry method. Anal Chem 2006;78(17):6153-9. http://dx.doi.org/10.1021/ac060250j

31. Ciminiello P, Dell'Aversano C, Fattorusso E, Forino M, Tartaglione L, Grillo C, et al. Putative palytoxin and its new analogue, ovatoxin-a, in Ostreopsis ovata collected along the Ligurian coasts during the 2006 toxic outbreak. J Am Soc Mass Spectrom 2008;19:111-20. http://dx.doi.org/10.1016/j.jasms.2007.11.001

32. Ciminiello P, Dell'Aversano C, Dello Iacovo E, Fattorusso E, Forino M, Grauso L, et al. Complex palytoxin-like profile of Ostreopsis ovata. Identification of four new ovatoxins by high-resolution liquid chromatography/mass spectrometry. Rapid Commun Mass Spectrom 2010;24:2735-44. http://dx.doi.org/10.1002/rcm.4696

33. Ciminiello P, Dell'Aversano C, Dello Iacovo E, Fattorusso E, Forino M, Grauso L, et al. Isolation and structure elucidation of Ovatoxin-a, the major toxin produced by Ostreopsis ovata. J Am Chem Soc 2012;134:1869-75. http://dx.doi.org/10.1021/ja210784u

34. Rossi R, Castellano V, Scalco E, Serpe L, Zingone A, Soprano V. New palytoxin-like molecules in Mediterranean Ostreopsis cf. ovata (dinoflagellates) and in Palythoa tuberculosa detected by liquid chromatography-electrospray ionization time-of-flight mass spectrometry. Toxicon 2010;56:1381-7. http://dx.doi.org/10.1016/j.toxicon.2010.08.003

35. Ciminiello P, Dell'Aversano C, Iacovo ED, Fattorusso $\mathrm{E}$, Forino $\mathrm{M}$, Tartaglione $\mathrm{L}$, et al. Unique toxin profile of a Mediterranean Ostreopsis cf. ovata strain: HR LC-MS(n) characterization of ovatoxin-f, a new palytoxin congener. Chem Res Toxicol 2012;25(6):1243-52. http://dx.doi.org/10.1021/tx300085e

36. Habermann E. Palytoxin acts through $\mathrm{Na}^{+}, \mathrm{K}^{+}$-ATPase Toxicon 1989;27:1175-87. http://dx.doi.org/10.1016/0041-0101(89)90026-3

37. Kim SY, Marx KA, Wu CH. Involvement of the $\mathrm{Na}, \mathrm{K}-$ ATPase in the induction of ion channels by palytoxin. Naunyn Schmiedeberg's Arch Pharmacol 1995;351:542-54. http://dx.doi.org/10.1007/BF00171047

38. Wu CH. Palytoxin: membrane mechanism of action. Toxicon 2009;54:1183-9. http://dx.doi.org/10.1016/j.toxicon.2009.02.030

39. Rossini GP and Bigiani A. Palytoxin action on the $\mathrm{Na}(+), \mathrm{K}(+)$-ATPase and the disruption of ion equilibria in biological systems. Toxicon 2011;57:429-39. http://dx.doi.org/10.1016/j.toxicon.2010.09.011

40. Durando P, Ansaldi F, Oreste P, Moscatelli P, Marensi L, Grillo C, et al. Ostreopsis ovata and human health: epidemi- 
ological and clinical features of respiratory syndrome outbreaks from a two year syndromic surveillance, 2005-2006, in north-west Italy. Euro Surveill 2007;12(23).

41. Kermarec F, Dor F, Armengaud A, Charlet F, Kantin R, Sauzade D, et al. Health risks related to Ostreopsis ovata in recreational waters. Env Risques Santé 2008;7:357-63.

42. Tichadou L, Glaizal M, Armengaud A, Grossel H, Lemée $\mathrm{R}$, Kantin R, et al. Health impact of unicellular algae of the Ostreopsis genus blooms in the Mediterranean Sea: experience of the French Mediterranean coast surveillance network from 2006 to 2009. Clin Toxicol 2010;48:839-44. http://dx.doi.org/10.3109/15563650.2010.513687

43. Tubaro A, Durando P, Del Favero G, Ansaldi F, Icardi G, Deeds JR, et al. Case definitions for human poisonings postulated to palytoxins exposure. Toxicon 2011;57:478-95.

http://dx.doi.org/10.1016/j.toxicon.2011.01.005

44. Pfannkuchen M, Godrijan J, Mariić Pfannkuchen D, Iveša L, Kružić $\mathrm{P}$, Ciminiello $\mathrm{P}$, et al. Toxin-producing Ostreopsis cf. ovata are likely to bloom undetected along coastal areas. Environ Sci Technol 2012;46:5574-82. http://dx.doi.org/10.1021/es300189h

45. Deeds JR, Handy SM, White KD, Reimer JD. Palytoxin found in Palythoa sp. Zoanthids (Anthozoa, Hexacorallia) sold in the home aquarium trade. PLoS One 2011;6:1-9. http://dx.doi.org/10.1371/journal.pone.0018235

46. Nordt SP, Wu J, Zahller S, Clark RF, Cantrell FL. Palytoxin poisoning after dermal contact with zoanthid coral. $J$ Emerg Med 2009;40(4):397-9. http://dx.doi.org/10.1016/j.jemermed.2009.05.004

47. Hoffmann K, Hermanns-Clausen M, Buhl C, Buchler MW, Schemmer P, Mebs D, et al. A case of palytoxin poisoning due to contact with zoanthid corals through skin injury. Toxicon 2008;51:1535-7. http://dx.doi.org/10.1016/j.toxicon.2008.03.009

48. Pelin M, Zanette C, De Bortoli M, Sosa S, Della Loggia $\mathrm{R}$, Tubaro A, et al. Effects of the marine toxin palytoxin on human skin keratinocytes: role of ionic imbalance. Toxicology 2011;282:30-8. http://dx.doi.org/10.1016/j.tox.2011.01.010

49. Gibbs S. In vitro irritation models and immune reactions. Skin Pharmacol Physiol 2009;22:103-13. http://dx.doi.org/10.1159/000178869

50. Artigas $\mathrm{P}$, Gadsby DC. Ion channel-like properties of the $\mathrm{Na}^{+}$/ $\mathrm{K}^{+}$pump. Ann NY Acad Sci 2002;976:31-40 http://dx.doi.org/10.1111/j.1749-6632.2002.tb04711.x

51. Frelin C, Van Renterghem C. Palytoxin. Recent electrophysiological and pharmacological evidence for several mechanisms of action. Gen Pharmacol 1995;26:33-7. http://dx.doi.org/10.1016/0306-3623(94)00133-8

52. Ares IR, Cagide E, Louzao MC, Espina B, Vieytes MR, Yasumoto T, et al. Ostreocin-D impact on globular actin of intact cells. Chem Res Toxicol 2009;22:374-81. http://dx.doi.org/10.1021/tx800273f

53. Sheridan RE, Deshpande SS, Adler M. Cytotoxic action of palytoxin on aortic smooth muscle cells in culture. J Appl Toxicol 2005;25:365-73. http://dx.doi.org/10.1002/jat.1080

54. Schilling WP, Snyder D, Sinkins WG, Estacion M. Palytoxin-induced cell death cascade in bovine aortic endothelial cells. Am J Physiol Cell Physiol 2006;291:657-67. http://dx.doi.org/10.1152/ajpcell.00063.2006

55. Mebs D. Occurrence and sequestration of toxins in food chains. Toxicon 1998;36:1519-22. http://dx.doi.org/10.1016/S0041-0101(98)00143-3
56. Yasumoto T, Yasumura D, Ohizumi Y, Takahashi M, Alcala Ac, Alcala LC. Palytoxin in two species of xanthid crab from the Philippines. Agric Biol Chem 1986;50:163-7. http://dx.doi.org/10.1271/bbb1961.50.163

57. Noguchi T, Hwang DF, Arakawa O, Daigo K, Sato S, Ozaki $\mathrm{H}$, et al. Palytoxin as the causative agent in the parrotfish poisoning. In: Gopalakrishnakone P, Tan CK (Eds.). Progress in venom and toxin research: Proceedings of the first Asia-Pacific Congress on Animal, Plant and Microbial Toxins. Singapore: Faculty of Medicine, National University of Singapore; 1987. p. 325-35.

58. Alcala AC, Alcala LC, Garth JS, Yasumura D, Yasumoto T. Human fatality due to ingestion of the crab Demania reynaudii that contained a palytoxin-like toxin. Toxicon 1988;26:105-7. http://dx.doi.org/10.1016/0041-0101(88)90142-0

59. Onuma Y, Satake M, Ukena T, Roux J, Chanteau S, Rasolofonirina $\mathrm{N}$, et al. Identification of putative palytoxin as the cause of clupeotoxism. Toxicon 1999;37:55-65. http://dx.doi.org/10.1016/S0041-0101(98)00133-0

60. Taniyama S, Mahmud Y, Terada M, Takatani T, Arakawa $\mathrm{O}$, Noguki, T. Occurrence of a food poisoning incident by PLTX from a serranid Epinephelus sp. in Japan. $J$ Nat Toxins 2002;11:277-82.

61. Aligizaki K, Katikou P, Nikolaidis G, Panou A. First episode of shellfish contamination by palytoxin-like compounds from Ostreopsis species (Aegean Sea, Greece). Toxicon 2008; 51:418-27. http://dx.doi.org/10.1016/j.toxicon.2007.10.016

62. Aligizaki K, Katikou $\mathrm{P}$, Milandri A, Diogène J. Occurrence of palytoxin-group toxins in seafood and future strategies to complement the present state of the art. Toxicon 2011;57:390-9. http://dx.doi.org/10.1016/j.toxicon.2010.11.014

63. EFSA Panel on Contaminants in the Food Chain (CONTAM). Scientific opinion on marine biotoxins in shellfish; Palytoxin group. EFSA J 2009;7(12)1393:38. http://dx.doi.org/10.2903/j.efsa.2009.1393

64. Ciminiello P, Dell'Aversano C, Dello Iacovo E, Fattorusso E, Forino M, Tartaglione L. LC-MS of palytoxin and its analogues: state of the art and future perspectives. Toxicon 2011;57:376-89. http://dx.doi.org/10.1016/j.toxicon.2010.11.002

65. Amzil Z, Sibat M, Chomerat N, Grossel H, MarcoMiralles F, Lemee R, et al. Ovatoxin-a and palytoxin accumulation in seafood in relation to Ostreopsis cf. ovata blooms on the French Mediterranean coast. Mar Drugs 2012;10:477-96. http://dx.doi.org/10.3390/md10020477

66. Bellocci M, Ronzitti G, Milandri A, Melchiorre N, Grillo $\mathrm{C}$, Poletti R, et al. A cytolytic assay for the measurement of palytoxin based on a cultured monolayer cell line. Anal Biochem 2008;374:48-55. http://dx.doi.org/10.1016/j.ab.2007.10.033

67. Wiles JS, Vick JA, Christensen MK. Toxicological evaluation of palytoxin in several animal species. Toxicon 1974;12:427-33. http://dx.doi.org/10.1016/0041-0101(74)90011-7

68. Rhodes LL, Munday R. Palytoxins: a risk to human health? In: Proceedings of the $20^{\text {th }}$ Marine Biotoxin Science Workshop. Wellington New Zealand: New Zealand Food Safety Authorities 23; 2004

69. Ito E, Yasumoto T. Toxicological studies on palytoxin and ostreocin-D administered to mice by three different routes. Toxicon 2009;54:244-51. http://dx.doi.org/10.1016/j.toxicon.2009.04.009

70. Sosa S, Del Favero G, De Bortoli M, Vita F, Soranzo MR, Beltramo D, et al. Palytoxin toxicity after acute oral adminis- 
tration in mice. Toxicol Lett 2009;191:253-9. http://dx.doi.org/10.1016/j.toxlet.2009.09.009

71. Tubaro A, Del Favero G, Beltramo D, Ardizzone $\mathrm{M}$, Forino $\mathrm{M}$, De Bortoli $\mathrm{M}$, et al. Acute oral toxicity in mice of a new palytoxin analog: 42-hydroxy-palytoxin. Toxicon 2011;57:755-763. http://dx.doi.org/10.1016/j.toxicon.2011.02.009

72. Ciminiello P, Dell'Aversano C, Dello Iacovo E, Fattorusso E, Forino M, Grauso L, et al. Stereostructure and biological activity of 42-hydroxy-palytoxin: a new palytoxin analogue from Hawaiian Palythoa subspecies. Chem Res Toxicol 2009;22:1851-9. http://dx.doi.org/10.1021/tx900259v
73. Del Favero G, Florio C, Codan B, Sosa S, Poli M, Sbaizero $\mathrm{O}$, et al. The stretch-activated channel blocker $\mathrm{Gd}^{3+}$ reduces palytoxin toxicity in primary cultures of skeletal muscle cells. Chem Res Toxicol 2012;25:1912-20. http://dx.doi.org/10.1021/tx300203x

74. Bellocci M, Sala GL, Prandi S. The cytolytic and cytotoxic activities of palytoxin. Toxicon 2011;57:449-59. http://dx.doi.org/10.1016/j.toxicon.2010.12.013

75. Pelin M, Sosa S, Della Loggia R, Poli M, Tubaro A, Decorti G, et al. The cytotoxic effect of palytoxin on Caco-2 cells hinders their use for in vitro absorption studies. Food Chem Toxicol 2012;50:206-11. http://dx.doi.org/10.1016/j.fct.2011.10.032 